Published in final edited form as:

Wiley Interdiscip Rev Membr Transp Signal. 2012 ; 1(6): 731-742. doi:10.1002/wmts.61.

\title{
$\mathrm{P} 2 \mathrm{Y}$ receptors and kidney function
}

\author{
Volker Vallon, \\ Department of Medicine, University of California San Diego, San Diego, CA 92161, USA; VA San \\ Diego Healthcare System, San Diego California, San Diego, CA 92161, USA; Department of \\ Pharmacology, University of California San Diego, La Jolla, CA 92093, USA \\ James Stockand, and \\ Department of Physiology, University of Texas Health Science Center at San Antonio, San \\ Antonio, TX 78229-3900, USA
}

\section{Timo Rieg}

Department of Medicine, University of California San Diego, San Diego, CA 92161, USA; VA San Diego Healthcare System, San Diego California, San Diego, CA 92161, USA

Volker Vallon: vvallon@ucsd.edu

\section{Abstract}

Cellular release of nucleotides is of physiological importance to regulate and maintain cell function and integrity. Also in the tubular and collecting duct system of the kidney, nucleotides are released in response to changes in cell volume or luminal flow rate and act in a paracrine and autocrine way on basolateral and luminal P2Y receptors. Recent studies using gene knockout mice assigned a prominent role to $\mathrm{G}$ protein-coupled $\mathrm{P} 2 \mathrm{Y}_{2}$ receptors, which are activated by both ATP and UTP. The antidiuretic hormone, arginine-vasopressin (AVP), and possibly an increase in collecting duct cell volume induce ATP release. The subsequent activation of $\mathrm{P}_{2} \mathrm{Y}_{2}$ receptors inhibits AVP-induced cAMP formation and water reabsorption, which stabilizes cell volume and facilitates water excretion. An increase in $\mathrm{NaCl}$ intake enhances luminal release of ATP and UTP in the aldosterone-sensitive distal nephron which by activating apical $\mathrm{P} 2 \mathrm{Y}_{2}$ receptors and phospholipase $\mathrm{C}$ lowers the open probability of the epithelial sodium channel $\mathrm{ENaC}$, thereby facilitating sodium excretion. Thus, the renal ATP/UTP/P2 $\mathrm{Y}_{2}$ receptor system not only serves to preserve cell volume and integrity but is also regulated by stimuli that derive from body $\mathrm{NaCl}$ homeostasis. The system also inhibits $\mathrm{ENaC}$ activity during aldosterone escape, i.e. when sodium reabsorption via $\mathrm{ENaC}$ is inappropriately high. The $\mathrm{P}_{2} \mathrm{Y}_{2}$ receptor tone inhibits the expression and activity of the Na-K-2Cl cotransporter NKCC2 in the thick ascending limb and mediates vasodilation. While the role of other P2Y receptors in the kidney is less clear, the ATP/UTP/P2 $\mathrm{Y}_{2}$ receptor system regulates $\mathrm{NaCl}$ and water homeostasis and blood pressure.

Autocrine and paracrine mechanisms are important for the regulation of renal function and to maintain the integrity of kidney cells. Cellular release of ATP and other nucleotides constitute such local intrarenal mechanisms. The nucleotide release in renal epithelia occurs across both the apical and basolateral membranes with a proposed predominant release across the apical membrane ${ }^{1-4}$. Cell membrane ecto-nucleotidases degrade extracellular nucleotides, and the expression pattern of these enzymes along the nephron and collecting duct (CD) system may provide functional clues $1 ; 5 ; 6$. The released ATP and other nucleotides affect cellular function by activating ionotropic $\mathrm{P} 2 \mathrm{X}$ receptors and/or metabotropic G protein-coupled P2Y receptors in the cell membrane. The P2Y receptor family currently includes eight receptor subtypes $\left(\mathrm{P}_{2} \mathrm{Y}_{1,2,4,6,11-14}\right)^{7-9}$ and their role in the 
kidney is the focus of this review. The recent availability of gene knockout animals has provided an invaluable tool to better define the function and relevance of $\mathrm{P} 2 \mathrm{Y}$ receptors in the kidney. These studies, in particular, point to a prominent role for the $\mathrm{P}_{2} \mathrm{Y}_{2}$ receptor in the regulation of renal electrolyte and water transport. Where evidence is available for a functional role of other P2Y receptor subtypes, this will be mentioned. For a more detailed discussion, the interested reader is referred to recent reviews on the role of $\mathrm{P} 2 \mathrm{Y}$ receptors in the kidney ${ }^{1-3 ; 10-13}$.

\section{EXPRESSION AND FUNCTION OF P2Y RECEPTORS IN RENAL VASCULATURE}

Expression data of $\mathrm{P} 2 \mathrm{Y}$ receptors in the renal vasculature are sparse compared to other parts of the kidney. One study proposed expression of $\mathrm{P}_{2} \mathrm{Y}_{1}$ and $\mathrm{P}_{2} \mathrm{Y}_{2}$ receptor in the smooth muscle cells of rat renal artery ${ }^{14}$, another study proposed that afferent and efferent arterioles express $\mathrm{P}_{2} \mathrm{Y}_{1}$ receptors ${ }^{15}$. Little is known about the specific role of $\mathrm{P} 2 \mathrm{Y}$ receptor subtypes beyond the general notion that the sensitivity of the renal vasculature appears to be greater to $\mathrm{P} 2 \mathrm{X}$ receptor stimulation than $\mathrm{P} 2 \mathrm{Y}$ under basal conditions, and that $\mathrm{P} 2 \mathrm{X}$ receptor stimulation causes vasoconstriction, whereas activation of $\mathrm{P} 2 \mathrm{Y}$ receptors in the kidney causes vasoconstriction or tone-dependent vasodilation (for review see ${ }^{16}$ ). Studies in the blood perfused juxtamedullary nephron indicated afferent arteriolar vasoconstriction when P2Y-selective agonists like 2-methylthio ATP (preferred acting on P2 $\mathrm{Y}_{1}$ ) and UTP (P2 $\mathrm{Y}_{2}$ and/or $\mathrm{P}_{2} \mathrm{Y}_{4}$ ) were applied ${ }^{17}$. ATP, UTP and 2-methylthio ATP caused a dose-dependent vasoconstriction in isolated rat renal arteries pre-contracted with $\mathrm{KCl}^{14}$, a maneuver that has been shown to impair endothelial-dependent vasorelaxation ${ }^{18 ; 19}$. In the isolated perfused rat kidney 2-methylthio ATP, ADP ( $\left.\mathrm{P}^{2} \mathrm{Y}_{1 / 12}\right)$, ATP $\gamma \mathrm{S}\left(\mathrm{P}_{2} \mathrm{Y}_{2}\right)$ and UTP produced vasodilatation at low doses and vasoconstriction at high doses ${ }^{20}$. The vasodilation response appeared to be mediated by an endothelial factor, including nitric oxide (NO) and endothelial-derived relaxation factor (EDHF), and independent of prostaglandin formation ${ }^{20-22}$. Indirect in vivo evidence for a tonic vasodilatatory role of $\mathrm{P}_{2} \mathrm{Y}_{2}$ receptor activation in the kidney comes from $\mathrm{P}_{2} \mathrm{Y}_{2}$ receptor knockout mice $\left(\mathrm{P}_{2} \mathrm{Y}_{2}-/-\right)$ which show an increased renal vascular resistance compared to wild-type mice (WT) ${ }^{23}$. Systemic application of a $\mathrm{P}_{2} \mathrm{Y}_{2 / 4}$ receptor agonist (INS45973) dose-dependently decreased blood pressure in wild-type mice and to a similar extent in endothelial nitric oxide synthase knockout mice ${ }^{24}$. By contrast, INS45973 increased blood pressure in $\mathrm{P}_{2} \mathrm{Y}_{2}-/-$ mice. These studies indicated that $\mathrm{P} 2 \mathrm{Y}_{2}$ receptor activation induces a systemic vasodilation that is independent of endothelial NO synthase, implicating a role for EDHF, and that activation of $\mathrm{P}_{2} \mathrm{Y}_{4}$ receptors on smooth muscle may induce vasoconstriction ${ }^{24}$. Figure 1 proposes a general concept for the role of $\mathrm{P} 2 \mathrm{Y}$ receptors in the regulation of vascular tone, which may in part apply to the renal resistance vessels. Much more information is required on the role of P2Y receptors on the afferent versus efferent arteriole, the glomerular capillaries, and the postglomerular cortical and medullary vasculature.

\section{EXPRESSION OF P2Y RECEPTORS IN RENAL EPITHELIA}

Table 1 summarizes the renal epithelial expression of $\mathrm{P} 2 \mathrm{Y}$ receptors based on analysis of mRNA and protein expression in rat kidney. Defining the functional role of specific P2Y receptor subtypes has been hampered by the lack of receptor subtype specific antagonists. First and preliminary information on the role of a specific $\mathrm{P} 2 \mathrm{Y}$ receptor subtype has been obtained based on their differences in agonist preference, e.g., $\mathrm{P}_{2} \mathrm{Y}_{6}$ receptors are activated by UDP>UTP>ADP; in rodents only the $\mathrm{P}_{2} \mathrm{Y}_{2}$ and $\mathrm{P} 2 \mathrm{Y}_{4}$ receptor subtypes are similarly activated by ATP and UTP ${ }^{8 ; 9}$ and named "P2 $\mathrm{Y}_{2}$-like" in the following. Table 2 summarizes the latter kind of studies that have been performed on the proximal tubule. These studies propose a potential role of $\mathrm{P}_{2} \mathrm{Y}_{2}$-like receptors in the regulation of gluconeogenesis in the 
proximal tubule, but further studies are needed to identify the receptor subtype and the physiological relevance.

\section{FLOW-DEPENDENT NUCLEOTIDE RELEASE AND ACTIVATION OF P2Y 2 RECEPTORS IN THICK ASCENDING LIMB}

Binding studies ${ }^{25 ; 26}$ and studies of the effects of ATP and UTP on $\left[\mathrm{Ca}^{2+}\right]_{\mathrm{i}}{ }^{27}$ provided evidence for the presence of $\mathrm{P}_{2} \mathrm{Y}_{2}$-like receptors in thick ascending limb (TAL), i.e. $\mathrm{P} 2 \mathrm{Y}_{2}$ and/or $\mathrm{P}_{2} \mathrm{Y}_{4}$ receptors. Both receptors have been detected in TAL on the mRNA and/or protein level (Table 1). Studies in perfused medullary TAL of WT and knockout mice indicated that increasing the perfusion pressure and thereby the luminal flow rate induces apical and basolateral release of nucleotides, which by activation of apical and basolateral $\mathrm{P}_{2} \mathrm{Y}_{2}$ receptors triggers increases in $\left[\mathrm{Ca}^{2+}\right]_{\mathrm{i}}{ }^{28}$ and $\left[\mathrm{Ca}^{2+}\right]_{\mathrm{i}}$ oscillations ${ }^{29}$. First evidence for an inhibitory influence of $\mathrm{P}_{2} \mathrm{Y}_{2}$ receptor tone on $\mathrm{NaCl}$ reabsorption in $\mathrm{TAL}$ was provided in $\mathrm{P}_{2} \mathrm{Y}_{2}-/-$ mice which have greater expression of $\mathrm{NKCC} 2{ }^{23 ; 30}$ and furosemide-induced natriuresis compared with WT mice ${ }^{23}$. The ATP/UTP/P2 $\mathrm{Y}_{2}$ receptor system may serve to inhibit and limit $\mathrm{NaCl}$ reabsorption in TAL, which may support and interact with basolateral $\mathrm{P} 2 \mathrm{X}$ receptors ${ }^{31}$ and the adenosine system ${ }^{32}$ in the metabolic control of TAL function.

\section{THE ATP/UTP/P2Y 2 RECEPTOR SYSTEM INHIBITS THE EPITHELIAL SODIUM CHANNEL}

The expression of $\mathrm{P}_{2} \mathrm{Y}_{2}$ receptor protein has been demonstrated in both apical and basolateral membranes of rat collecting ducts (CD) (Table 1). Studies in the isolated perfused rabbit and mouse cortical collecting duct (CCD) indicated the expression of both basolateral and luminal $\mathrm{P}_{2} \mathrm{Y}_{2}$-like receptors in principal cells ${ }^{33-35}$. These receptors are linked to activation of phospholipase $\mathrm{C}$ and increases in $\left[\mathrm{Ca}^{2+}\right]_{\mathrm{i}}^{33-35}$. In 1996, experiments in cultured rabbit connecting tubule (CNT) and CCD cells provided first evidence for an inhibitory effect of ATP on sodium transport via the epithelial sodium channel, $\mathrm{ENaC}$, an effect that appeared to be independent of changes in $\left[\mathrm{Ca}^{2+}\right]_{i}{ }^{36}$. Subsequent studies in M-1 mouse CCD cells $37 ; 38$ and in isolated perfused CCD of mice kept on a low $\mathrm{NaCl}$ diet 39 indicated that both luminal and basolateral activation of $\mathrm{P}_{2} \mathrm{Y}_{2}$-like receptors can inhibit ENaC-mediated $\mathrm{Na}^{+}$reabsorption independent of an increase in $\left[\mathrm{Ca}^{2+}\right]_{\mathrm{i}}$.

\section{Activation of $\mathrm{P}_{2} \mathrm{Y}_{2}$ receptors reduces $\mathrm{ENaC}$ open probability}

The initial in vivo evidence for an inhibitory effect of luminal ATP on $\mathrm{Na}^{+}$reabsorption in the $\mathrm{CD}$ was obtained in 2005 in microperfusion experiments in rats maintained on a low $\mathrm{Na}^{+}$ diet ${ }^{40}$. In 2007, studies in $\mathrm{P}_{2} \mathrm{Y}_{2}-/-$ mice revealed normal amiloride-sensitive $\mathrm{Na}^{+}$ reabsorption despite lower renal expression of the a-subunit of ENaC compared with WT mice ${ }^{23}$, indicating greater intrinsic activity of ENaC. Moreover, smaller increases in plasma aldosterone were sufficient to adapt renal $\mathrm{Na}^{+}$excretion to restricted dietary $\mathrm{NaCl}$ intake in $\mathrm{P}_{2} \mathrm{Y}_{2}-/-$ mice ${ }^{23}$, a finding that could also be explained by greater intrinsic $\mathrm{ENaC}$ activity. Subsequent patch-clamp studies in freshly isolated split open CNTs and CCDs of knockout and WT mice demonstrated that locally released ATP acts in an autocrine/paracrine manner to tonically inhibit the open probability $\left(\mathrm{P}_{\mathrm{O}}\right)$ of ENaC via activation of $\mathrm{P} 2 \mathrm{Y}_{2}$ receptors ${ }^{41 ; 42}$ (Figure 2). Thus, a lack of $\mathrm{P}_{2} \mathrm{Y}_{2}$ receptor activation in mice resulted in greater $\mathrm{ENaC} \mathrm{P}_{\mathrm{O}}$. The latter was in part compensated by decreasing circulating aldosterone concentrations and $\mathrm{ENaC}$ expression to normalize net $\mathrm{ENaC}$ activity. 
Inhibition of ENaC open probability by $\mathrm{P}_{2} \mathrm{Y}_{2}$ receptors involves activation of phospholipase $\mathbf{C}$ and hydrolysis of anionic phospholipids

In the A6 cell line, the P2Y receptor agonist ATP $\gamma \mathrm{S}$ reduced $\mathrm{ENaC} \mathrm{P}_{\mathrm{O}}$ by activation of phospholipase $\mathrm{C}^{43}$ and hydrolysis of the anionic phospholipid, phosphatidylinositol 4,5bisphosphate $\left(\mathrm{PIP}_{2}\right)^{44}$. Studies in mpkCCDc14 principal cells showed that ATP decreases plasma membrane $\mathrm{PIP}_{2}$ levels and $\mathrm{ENaC} \mathrm{P}_{\mathrm{O}}$ with similar time courses ${ }^{45}$. Moreover, direct activation of PLC mimicked ATP action on $\mathrm{ENaC}$ in isolated CNT/CCD, and direct PLC stimulation decreased ENaC activity in CNT/CCD from $\mathrm{P} 2 \mathrm{Y}_{2}-/-$ mice ${ }^{41}$. Whole-cell patch clamp studies of principal cells of split-open $\mathrm{CD}$ from sodium-restricted rats confirmed that activation of $\mathrm{P} 2$ receptors (most likely the $\mathrm{P}_{2} \mathrm{Y}_{2}$ and/or $\mathrm{P}_{2} \mathrm{Y}_{4}$ subtype) inhibited $\mathrm{ENaC}$ activity via activation of PLC ${ }^{46}$. Experiments in Xenopus oocytes and M-1 mouse CCD cells ${ }^{47}$ as well as A6 cells ${ }^{48}$ provided further evidence for the following mechanism for the regulation of $\mathrm{ENaC}$ by $\mathrm{P}_{2} \mathrm{Y}_{2}$ receptors ${ }^{49}$ (Figure 3): under resting conditions the inner leaflet of the lipid bilayer contains a high concentration of $\mathrm{PIP}_{2}$, the latter binding the Nterminus of the $\beta$-subunit of $\mathrm{ENaC}$, thereby maintaining the $\mathrm{ENaC}$ channel open.

Stimulation of $\mathrm{P} 2 \mathrm{Y}_{2}$ receptors activates phospholipase $\mathrm{C}$, which hydrolyzes and lowers the concentration of $\mathrm{PIP}_{2}$ with resultant decreases in $\mathrm{PIP}_{2}$ binding to the $\mathrm{N}$-terminus of $\beta$-ENaC. The latter reduces ENaC activity by lowering $\mathrm{P}_{\mathrm{O}}$.

\section{Dietary $\mathrm{NaCl}$ inhibits the open probability of $\mathrm{ENaC}$ in connecting tubule/cortical collecting duct by enhancing apical $\mathrm{P}_{2} \mathrm{Y}_{2}$ receptor tone}

Patch-clamp studies in freshly isolated mouse CNT/CCD demonstrated that ENaC $\mathrm{P}_{\mathrm{O}}$ is negatively regulated by dietary $\mathrm{NaCl}^{42 ; 50}$. Gene-knockout of $\mathrm{P}_{2} \mathrm{Y}_{2}$ receptors in mice did not affect the inhibitory effect of dietary $\mathrm{NaCl}$ on the number of ENaCs per patch $(\mathrm{N})$ but completely prevented the dietary $\mathrm{NaCl}$-induced lowering of $\mathrm{ENaC}_{\mathrm{O}}$ (Figure 2) ${ }^{42}$. Inhibition of apical ATP/P2Y-receptor signaling (using suramin to block the receptors and hexokinase/glucose to remove ATP) in WT mice prevented the inhibitory influence of dietary $\mathrm{NaCl}$ intake on $\mathrm{ENaC} \mathrm{P}_{\mathrm{O}}$ (and mimicked the phenotype of $\mathrm{P}_{2} \mathrm{Y}_{2}-/-$ mice), consistent with a dietary $\mathrm{NaCl}$ dependent release of ATP/UTP from CNT/CCD that is preserved after harvesting these segments (Figure 2$)^{42}$. In accordance, a greater $\mathrm{NaCl}$ intake was associated with increased urinary concentrations (relative to creatinine) of UTP ${ }^{42}$, the ATP hydrolytic product, ADP ${ }^{42}$, and ATP ${ }^{51}$. Moreover, the urinary concentrations of UTP and ATP were within the range of concentrations shown to alter ENaC activity in freshly isolated split open $\mathrm{CNT} / \mathrm{CCD}{ }^{51}$.

\section{THE RELEVANCE OF THE ATP/UTP/P2 $Y_{2}$ RECEPTOR SYSTEM FOR NACL HOMEOSTASIS AND BLOOD PRESSURE REGULATION}

Deleting $\mathrm{P}_{2} \mathrm{Y}_{2}$ receptors in mice caused a NaCl-resistant increase in $\mathrm{BP}{ }^{23}$. A dysfunction of arterial baroreceptors has been implicated in genetic forms of $\mathrm{NaCl}$-sensitive hypertension in rats and humans ${ }^{52}$. In comparison, it was proposed that the increased $\mathrm{BP}$ in $\mathrm{P}_{2} \mathrm{Y}_{2}-/-$ mice is $\mathrm{NaCl}$-resistant due to an intact baroreceptor response, which lowers heart rate and tends to normalize renal $\mathrm{NaCl}$ excretion by inhibiting the sympathetic nervous tone and the reninangiotension-aldosterone system: changes in $\mathrm{NaCl}$ intake did not affect heart rate in WT mice but negatively regulated heart rate in $\mathrm{P}_{2} \mathrm{Y}_{2}-/-$ mice ${ }^{23}$. Moreover, plasma aldosterone concentrations were lower in $\mathrm{P}_{2} \mathrm{Y}_{2}-1-$ compared with WT mice on low, normal and high $\mathrm{NaCl}$ intake ${ }^{23}$.

$\mathrm{P}_{2} \mathrm{Y}_{2}-/-$ mice have an increased BP but amiloride-sensitive renal sodium excretion is not significantly increased compared with WT mice on a regular $\mathrm{NaCl}$ diet ${ }^{23}$, consistent with a similar net $\mathrm{ENaC}$ activity $\left(\mathrm{NP}_{\mathrm{O}}\right)$ in isolated $\mathrm{CNT} / \mathrm{CCD}$ patches harvested from $\mathrm{P}_{2} \mathrm{Y}_{2}-/-$ and WT animals on normal $\mathrm{NaCl}$ diet ${ }^{42}$. Lower plasma aldosterone concentrations can explain 
the lower renal aENaC expression observed in $\mathrm{P}_{2} \mathrm{Y}_{2}-/-$ mice which may normalize $\mathrm{ENaC}$ activity in the presence of greater $\mathrm{ENaC}_{\mathrm{O}}$. Greater $\mathrm{BP}$ despite "normal" net $\mathrm{ENaC}$ activity implies additional BP-related defects in $\mathrm{P}_{2} \mathrm{Y}_{2}-/-$ mice, consistent with a proposed greater expression and activity of $\mathrm{NKCC} 2$ in the TAL ${ }^{23}$ and impaired vasodilation (see below).

Chronic application of DOCA plus high $\mathrm{NaCl}$ intake eliminated the differences in mineralocorticoid tone between $\mathrm{P}_{2} \mathrm{Y}_{2}-/-$ and WT mice, and unmasked greater net $\mathrm{ENaC}$ activity as well as $\mathrm{NaCl}$-sensitivity of BP in knockout compared with WT mice ${ }^{42}$. Furthermore, DOCA sensitized the number of active $\mathrm{ENaC}$ expression in the apical membrane to a $\mathrm{P}_{2} \mathrm{Y}_{2}$ receptor-mediated inhibitory influence, indicating that the influence of the ATP/UTP/P2 $\mathrm{Y}_{2}$ receptor system on $\mathrm{ENaC}$ goes beyond the regulation of $\mathrm{Po}^{42}$. Thus, $\mathrm{P}_{2} \mathrm{Y}_{2}$ receptor signaling also mediates the suppression of $\mathrm{ENaC}$ activity when sodium transport is activated by high levels of mineralocorticoids in combination with high $\mathrm{NaCl}$ intake as observed in aldosterone escape ${ }^{42 ; 51}$.

\section{Mechanisms involved in the regulation of luminal ATP/UTP release by dietary $\mathrm{NaCl}$}

The molecular mechanisms involved in the regulation of luminal ATP/UTP concentrations following changes in $\mathrm{NaCl}$ intake may include changes in nucleotide secretion and breakdown. The gap-junction protein, connexin 30 (Cx30), which may function as a hemichannel, has recently been implicated in flow-induced release of ATP in murine CD ${ }^{53}$, in $\mathrm{NaCl}$-induced increases in urinary $\mathrm{ATP} /$ creatinine ratios ${ }^{51}$ and $\mathrm{NaCl}$-induced suppression of $\mathrm{ENaC}_{\mathrm{O}} 54$, as well as in the normal DOCA escape of $\mathrm{ENaC}^{54}$. In contrast to Cx30-/mice, mice lacking $\mathrm{P}_{2} \mathrm{Y}_{2}$ receptors have lost completely the down-regulation of $\mathrm{ENaC}_{\mathrm{O}}$ by dietary $\mathrm{NaCl}$ or the upregulation of $\mathrm{ENaC}_{\mathrm{O}}$ by DOCA. Further studies are needed to test whether this reflects other pathways of ATP release and whether Cx30 is also a determinant of UTP release. The renal expression of rabbit and murine Cx30 is mostly restricted to intercalated cells of the CNT/CCD whereas Cx30 was found throughout the luminal membrane continuous from the medullary TAL to the medullary CD system in the rat kidney 55 indicating species differences.

In addition to changes in cell volume and luminal flow rate, the local release and possibly breakdown/conversion of ATP/UTP in the CNT/CCD may be directly or indirectly under control of hormones involved in $\mathrm{NaCl}$ homeostasis. Lowering $\mathrm{NaCl}$ intake or treatment with DOCA increased ENaC Po in isolated CNT/CCD in WT mice but not in $\mathrm{P}_{2} \mathrm{Y}_{2}-/-$ mice ${ }^{42}$. Moreover, mineralocorticoids enhance $\mathrm{ENaC}_{\mathrm{O}}$ in A6 cells ${ }^{56-58}$. Therefore, we speculate that mineralocorticoids increase $\mathrm{ENaC} \mathrm{P}_{\mathrm{O}}$ by suppressing the inhibitory influence of the ATP/UTP/P2Y 2 receptor system (Figure 3). During mineralocorticoid escape (e.g. DOCA plus high salt diet) ATP and/or UTP release may primarily be due to increases in cell volume $^{2 ; 59 ; 60}$ as a consequence of DOCA-induced overactive sodium transport and/or increases in tubular flow rate.

\section{$\mathrm{P}_{2}$ receptor activation also induces systemic vasodilation}

Whereas $\mathrm{P}_{2} \mathrm{Y}_{2}$ receptor knockout impaired renal $\mathrm{NaCl}$ excretion, acute activation of $\mathrm{P}_{2} \mathrm{Y}_{2}$ receptors inhibited renal sodium reabsorption and increased excretion ${ }^{24}$. Moreover, $\mathrm{P}_{2} \mathrm{Y}_{2}$ receptor activation mediated ATP-evoked relaxation of the murine aorta ${ }^{61}$ and an endothelial NO-independent BP lowering effect (implicating a role for EDHF) ${ }^{24}$ (Figure 1). Dual vascular and renal effects suggest the potential utility of $\mathrm{P}_{2} \mathrm{Y}_{2}$ agonism in the treatment of hypertension, and early genetic studies have identified polymorphisms in the gene for the $\mathrm{P}_{2} \mathrm{Y}_{2}$ receptor associated with essential hypertension in Japanese men ${ }^{62}$ and with BP in African Americans ${ }^{63}$. 


\section{A ROLE FOR P2Y ${ }_{2}$-LIKE RECEPTORS IN THE INHIBITION OF RENAL K+ SECRETION}

Patch-clamp studies ofthe apical membrane in split-open mouse CCD indicated that activation of $\mathrm{P}_{2} \mathrm{Y}_{2}$-like receptors inhibit the small-conductance $\mathrm{K}^{+}$channel of principal cells ${ }^{64}$. In contrast, in vitro studies have linked ATP and P2Y receptor activation to an increased activity of big-conductance $\mathrm{Ca}^{2+}$-activated $\mathrm{K}^{+}(\mathrm{BK})$ channels in intercalated cells ${ }^{65 ; 66}$. The BK channel is of particular interest since an increase in tubular flow can not only increase ATP release and $\mathrm{P} 2 \mathrm{Y}_{2}$ receptor activation ${ }^{28}$ but stimulates $\mathrm{K}^{+}$secretion via the $\mathrm{BK}$ channel in the $\mathrm{CNT} / \mathrm{CD}$, which may involve $\mathrm{P}_{2} \mathrm{Y}_{2}$ receptor-induced increases in $\left[\mathrm{Ca}^{2+}\right]_{i}^{66-69}$. Mice lacking $\mathrm{P}_{2} \mathrm{Y}_{2}$ receptors provided indirect evidence for facilitated renal $\mathrm{K}$ excretion on standard $\mathrm{K}^{+}$diet ${ }^{23}$, which would be consistent with the proposed inhibitory influence of $\mathrm{P}_{2} \mathrm{Y}_{2}$-like receptors on the small conductance $\mathrm{K}^{+}$channel in principal cells discussed above. Facilitation of urinary $\mathrm{K}^{+}$excretion in $\mathrm{P}_{2} \mathrm{Y}_{2}-/-$ versus WT mice dissipated in response to a high $\mathrm{K}^{+}$diet ${ }^{23}$, which may reflect increasing contributions of $\mathrm{P}_{2} \mathrm{Y}_{2}$ receptor stimulated BK channels under these conditions.

\section{P2Y $_{2}$ RECEPTOR ACTIVATION INHIBITS WATER TRANSPORT IN THE COLLECTING DUCT}

The anti-diuretic hormone arginine-vasopressin (AVP) is the primary regulator of water reabsorption in the renal $\mathrm{CD}$ and critically involved in the regulation of water balance and maintenance of plasma osmolality. AVP acts on the CD through the Gs protein-coupled vasopressin $\mathrm{V}_{2}$ receptor $\left(\mathrm{V}_{2} \mathrm{R}\right)$ to stimulate adenylyl cyclase (AC; in particular AC6 in the inner medulla) and thus the synthesis of cAMP ${ }^{70}$. cAMP activates protein kinase A (PKA), which phosphorylates the water channel aquaporin-2 (AQP2), thereby resulting in apical plasma membrane insertion/retrieval of AQP2 ${ }^{71}$ (Figure 4). In the following we outline the evidence that the CD system releases nucleotides like ATP/UTP in response to changes in cell volume and that these nucleotides act locally, including the activation of $\mathrm{P}_{2} \mathrm{Y}_{2}$ receptors, to modulate water transport and stabilize cell volume (for review see $2 ; 3 ; 72 ; 73$ ).

$\mathrm{P}_{2} \mathrm{Y}_{2}$ receptor protein expression has been localized in both apical and basolateral membranes of inner medullary collecting duct (IMCD) cells (Table 1), where it is positively related to the status of hydration ${ }^{74}$ and suppressed by chronic $V_{2} R$ agonism ${ }^{75}$. Several studies in rabbit and rat CCD, OMCD and IMCD used the application of ATP and/or UTP to provide evidence for a $\mathrm{P} 2 \mathrm{Y}_{2}$-like receptor that activates a $\mathrm{PLC} / \mathrm{Ca}^{2+} / \mathrm{PKC}$ signaling pathway and stimulates the release of prostaglandin $\mathrm{E}_{2}\left(\mathrm{PGE}_{2}\right)$ by activation of cyclooxygenase 1 thereby inhibiting cAMP formation and AVP-stimulated osmotic water permeability $33 ; 76-81$ (Figure 4). Studies in mpkCCD cells indicated that $\mathrm{P}_{2} \mathrm{Y}_{2}$ receptors are translocated to the basolateral membrane in response to AVP and mediate the downregulation of AQP2mediated water transport in response to basolateral ATP ${ }^{82}$.

$\mathrm{P} 2 \mathrm{Y}_{2}-1-$ mice have greater renal medullary expression of AQP2 compared with WT mice despite having similar urinary AVP concentrations ${ }^{23}$. $\mathrm{P}_{2} \mathrm{Y}_{2}$ receptors also appear to inhibit the medullary protein expression of AQP3 and the urea transporters UT-A1 and UT-A2 ${ }^{83}$ (Figures 4). Functional studies in knockout mice indicated that $\mathrm{P} 2 \mathrm{Y}_{2}$ receptor activation inhibits the AVP-induced cAMP-formation and water transport in the $\mathrm{CD}^{2 ; 23 ; 73}$. Moreover, measuring urinary ATP excretion while manipulating water homeostasis in $\mathrm{P}_{2} \mathrm{Y}_{2}-/-$ and WT mice (using water loading or $\mathrm{V}_{2} \mathrm{R}$ blockade) ${ }^{23}$ provided indirect evidence for a cell volume- and AVP-induced ATP release in CDs. The latter, through activation of $\mathrm{P}_{2} \mathrm{Y}_{2}$ receptors, inhibits water reuptake, stabilizes $\mathrm{CD}$ cell volume, and accelerates water excretion during hypotonic water loading (Figures 4 and 5)(for more detailed discussion see ${ }^{2 ; 73}$ ) as 
suggested for other epithelia and cells ${ }^{2}$ and consistent with studies showing AVP-stimulated nucleotide secretion in perfused mouse medullary TAL and $\mathrm{CCD}^{84}$.

\section{Conclusion}

Recent studies have established the physiological relevance of the luminal ATP/UTP/P2 $\mathrm{Y}_{2}$ receptor system for the regulation of $\mathrm{ENaC}$ open probability in the $\mathrm{CNT} / \mathrm{CCD}$ in response to changes in dietary $\mathrm{NaCl}$ and the relevance of the system for $\mathrm{NaCl}$ homeostasis and blood pressure regulation. These findings further indicate that local nucleotide/P2 receptor systems not only serve to preserve cell volume and integrity but may be regulated by stimuli that derive from body homeostasis. The implication of $\mathrm{Cx} 30$ in the regulation of nucleotide release by dietary $\mathrm{NaCl}$ is an important step to better understand the molecular nature and regulation of renal epithelial nucleotide release pathways. We have obtained novel insights about the renal epithelial localization and function of some P2Y receptors under basal condition but know very little about their pathophysiological relevance ${ }^{85}$. We are only beginning to understand the role of $\mathrm{P} 2 \mathrm{Y}$ receptor subtypes in the renal vasculature ${ }^{86}$ and renal nerves ${ }^{87}$. Less is known about the interactions between nucleotide and adenosine receptor-mediated signaling including the formation of receptor heteromultimers (e.g., for $\mathrm{P}_{2} \mathrm{Y}_{2}$ and adenosine $\mathrm{A}_{1}$ receptors 8;88) or between adrenergic and purinergic signaling 89 . Finally and to better define the functional role and therapeutic potential, specific and more stable P2Y receptor antagonists and agonists are very much needed.

\section{Acknowledgments}

Authors were supported by grants provided by the National Institutes of Health (R01HL094728, R01GM66232, R01DK56248, R01DK28602, P30DK079337 to VV; R01DK087460 to JS), the American Heart Association (GRNT3440038 to VV, 10SDG2610034 to TR), a Carl W. Gottschalk Research Grant of the American Society of Nephrology (to TR), and the Department of Veterans Affairs (VV, TR).

\section{Reference List}

1. Vallon V. P2 receptors in the regulation of renal transport mechanisms. Am J Physiol Renal Physiol. 2008; 294:F10-F27. [PubMed: 17977905]

2. Vallon V, Rieg T. Regulation of renal $\mathrm{NaCl}$ and water transport by the ATP/UTP/P2Y2 receptor system. Am J Physiol Renal Physiol. 2011; 301:F463-F475. [PubMed: 21715471]

3. Praetorius HA, Leipziger J. Intrarenal purinergic signaling in the control of renal tubular transport. Annu Rev Physiol. 2010; 72:377-393. [PubMed: 20148681]

4. Schwiebert EM. ATP release mechanisms, ATP receptors and purinergic signalling along the nephron. Clin Exp Pharmacol Physiol. 2001; 28:340-350. [PubMed: 11339211]

5. Vekaria RM, Shirley DG, Sevigny J, Unwin RJ. Immunolocalization of ectonucleotidases along the rat nephron. Am J Physiol Renal Physiol. 2006; 290:F550-F560. [PubMed: 16189292]

6. Kishore BK, Isaac J, Fausther M, Tripp SR, Shi H, Gill PS, Braun N, Zimmermann H, Sevigny J, Robson SC. Expression of NTPDase1 and NTPDase2 in murine kidney: relevance to regulation of P2 receptor signaling. Am J Physiol Renal Physiol. 2005; 288:F1032-F1043. [PubMed: 15632415]

7. Erb L, Liao Z, Seye CI, Weisman GA. P2 receptors: intracellular signaling. Pflugers Arch. 2006; 452:552-562. [PubMed: 16586093]

8. Abbracchio MP, Burnstock G, Boeynaems JM, Barnard EA, Boyer JL, Kennedy C, Knight GE, Fumagalli M, Gachet C, Jacobson KA, et al. International Union of Pharmacology LVIII: update on the P2Y G protein-coupled nucleotide receptors: from molecular mechanisms and pathophysiology to therapy. Pharmacol Rev. 2006; 58:281-341. [PubMed: 16968944]

9. Burnstock G. Purinergic signalling. Br J Pharmacol. 2006; 147(Suppl 1):S172-S181. [PubMed: 16402102]

10. Unwin RJ, Bailey MA, Burnstock G. Purinergic signaling along the renal tubule: the current state of play. News Physiol Sci. 2003; 18:237-241. [PubMed: 14614156] 
11. Wildman SS, Kang ES, King BF. ENaC, renal sodium excretion and extracellular ATP. Purinergic Signal. 2009; 5:481-489. [PubMed: 19306075]

12. Toney GM, Vallon V, Stockand JD. Intrinsic control of sodium excretion in the distal nephron by inhibitory purinergic regulation of the epithelial $\mathrm{Na}(+)$ channel. Curr Opin Nephrol Hypertens. 2012; 21:52-60. [PubMed: 22143248]

13. Bailey MA, Shirley DG. Effects of extracellular nucleotides on renal tubular solute transport. Purinergic Signal. 2009; 5:473-480. [PubMed: 19308675]

14. Knight GE, Oliver-Redgate R, Burnstock G. Unusual absence of endothelium-dependent or independent vasodilatation to purines or pyrimidines in the rat renal artery. Kidney Int. 2003; 64:1389-1397. [PubMed: 12969158]

15. Turner CM, Vonend O, Chan C, Burnstock G, Unwin RJ. The pattern of distribution of selected ATP-sensitive P2 receptor subtypes in normal rat kidney: an immunohistological study. Cells Tissues Organs. 2003; 175:105-117. [PubMed: 14605489]

16. Inscho EW. ATP, P2 receptors and the renal microcirculation. Purinergic Signal. 2009; 5:447-460. [PubMed: 19294530]

17. Nishiyama A, Rahman M, Inscho EW. Role of interstitial ATP and adenosine in the regulation of renal hemodynamics and microvascular function. Hypertens Res. 2004; 27:791-804. [PubMed: $15824461]$

18. He WJ, Fang TH, Ma X, Zhang K, Ma ZZ, Tu PF. Echinacoside elicits endothelium-dependent relaxation in rat aortic rings via an NO-cGMP pathway. Planta Med. 2009; 75:1400-1404. [PubMed: 19468974]

19. Chan BB, Kron IL, Flanagan TL, Kern JA, Hobson CE, Tribble CG. Impairment of vascular endothelial function by high-potassium storage solutions. Ann Thorac Surg. 1993; 55:940-945. [PubMed: 8466353]

20. Eltze M, Ullrich B. Characterization of vascular P2 purinoceptors in the rat isolated perfused kidney. Eur J Pharmacol. 1996; 306:139-152. [PubMed: 8813626]

21. Wangensteen R, Fernandez O, Sainz J, Quesada A, Vargas F, Osuna A. Contribution of endothelium-derived relaxing factors to P2Y-purinoceptor-induced vasodilation in the isolated rat kidney. Gen Pharmacol. 2000; 35:129-133. [PubMed: 11744234]

22. Churchill PC, Ellis VR. Pharmacological characterization of the renovascular P2 purinergic receptors. J Pharmacol Exp Ther. 1993; 265:334-338. [PubMed: 8474016]

23. Rieg T, Bundey RA, Chen Y, Deschenes G, Junger W, Insel PA, Vallon V. Mice lacking P2Y2 receptors have salt-resistant hypertension and facilitated renal $\mathrm{Na}+$ and water reabsorption. FASEB J. 2007; 21:3717-3726. [PubMed: 17575258]

24. Rieg T, Gerasimova M, Boyer JL, Insel PA, Vallon V. P2Y2 receptor activation decreases blood pressure and increases renal Na+ excretion. Am J Physiol Regul Integr Comp Physiol. 2011; 301:R510-R518. [PubMed: 21613580]

25. Chan CM, Unwin RJ, Burnstock G. Potential functional roles of extracellular ATP in kidney and urinary tract. Exp Nephrol. 1998; 6:200-207. [PubMed: 9639035]

26. Bailey MA, Hillman KA, Unwin RJ. P2 receptors in the kidney. J Auton Nerv Syst. 2000; 81:264270. [PubMed: 10869730]

27. Paulais M, Baudouin-Legros M, Teulon J. Extracellular ATP and UTP trigger calcium entry in mouse cortical thick ascending limbs. Am J Physiol. 1995; 268:F496-F502. [PubMed: 7900850]

28. Jensen ME, Odgaard E, Christensen MH, Praetorius HA, Leipziger J. Flow-induced [Ca2+]I increase depends on nucleotide release and subsequent purinergic signaling in the intact nephron. J Am Soc Nephrol. 2007; 18:2062-2070. [PubMed: 17554149]

29. Geyti CS, Odgaard E, Overgaard MT, Jensen ME, Leipziger J, Praetorius HA. Slow spontaneous $[\mathrm{Ca} 2+]$ i oscillations reflect nucleotide release from renal epithelia. Pflugers Arch. 2008; 455:1105-1117. [PubMed: 18026749]

30. Zhang Y, Listhrop R, Ecelbarger CM, Kishore BK. Renal sodium transporter/channel expression and sodium excretion in $\mathrm{P} 2 \mathrm{Y} 2$ receptor knockout mice fed a high- $\mathrm{NaCl}$ diet with/without aldosterone infusion. Am J Physiol Renal Physiol. 2011; 300:F657-F668. [PubMed: 21190950] 
31. Marques RD, de Bruijn PI, Sorensen MV, Bleich M, Praetorius HA, Leipziger J. Basolateral P2X receptors mediate inhibition of $\mathrm{NaCl}$ transport in mouse medullary thick ascending limb (mTAL). Am J Physiol Renal Physiol. 2012; 302:F487-F494. [PubMed: 22114208]

32. Vallon V, Muhlbauer B, Osswald H. Adenosine and kidney function. Physiol Rev. 2006; 86:901940. [PubMed: 16816141]

33. Rouse D, Leite M, Suki WN. ATP inhibits the hydrosmotic effect of AVP in rabbit CCT: evidence for a nucleotide P2u receptor. Am J Physiol. 1994; 267:F289-F295. [PubMed: 8067390]

34. Woda CB, Leite M Jr, Rohatgi R, Satlin LM. Effects of luminal flow and nucleotides on [Ca(2+)] (i) in rabbit cortical collecting duct. Am J Physiol Renal Physiol. 2002; 283:F437-F446. [PubMed: 12167594]

35. Deetjen P, Thomas J, Lehrmann H, Kim SJ, Leipziger J. The luminal P2Y receptor in the isolated perfused mouse cortical collecting duct. J Am Soc Nephrol. 2000; 11:1798-1806. [PubMed: 11004209]

36. Koster HP, Hartog A, van Os $\mathrm{CH}$, Bindels RJ. Inhibition of $\mathrm{Na}+$ and $\mathrm{Ca} 2+$ reabsorption by $\mathrm{P} 2 \mathrm{u}$ purinoceptors requires PKC but not Ca2+ signaling. Am J Physiol. 1996; 270:F53-F60. [PubMed: 8769822]

37. Cuffe JE, Bielfeld-Ackermann A, Thomas J, Leipziger J, Korbmacher C. ATP stimulates Clsecretion and reduces amiloride-sensitive $\mathrm{Na}+$ absorption in M-1 mouse cortical collecting duct cells. J Physiol. 2000; 524(Pt 1):77-90. [PubMed: 10747185]

38. Thomas J, Deetjen P, Ko WH, Jacobi C, Leipziger J. P2Y(2) receptor-mediated inhibition of amiloride-sensitive short circuit current in M-1 mouse cortical collecting duct cells. J Membr Biol. 2001; 183:115-124. [PubMed: 11562793]

39. Lehrmann H, Thomas J, Kim SJ, Jacobi C, Leipziger J. Luminal P2Y2 receptor-mediated inhibition of $\mathrm{Na}+$ absorption in isolated perfused mouse CCD. J Am Soc Nephrol. 2002; 13:10-18. [PubMed: 11752016]

40. Shirley DG, Bailey MA, Unwin RJ. In vivo stimulation of apical P2 receptors in collecting ducts: evidence for inhibition of sodium reabsorption. Am J Physiol Renal Physiol. 2005; 288:F1243F1248. [PubMed: 15687251]

41. Pochynyuk O, Bugaj V, Rieg T, Insel PA, Mironova E, Vallon V, Stockand JD. Paracrine regulation of the epithelial $\mathrm{Na}+$ channel in the mammalian collecting duct by purinergic P2Y2 receptor tone. J Biol Chem. 2008; 283:36599-36607. [PubMed: 18981175]

42. Pochynyuk O, Rieg T, Bugaj V, Schroth J, Fridman A, Boss GR, Insel PA, Stockand JD, Vallon V. Dietary Na+ inhibits the open probability of the epithelial sodium channel in the kidney by enhancing apical P2Y2-receptor tone. FASEB J. 2010; 24:2056-2065. [PubMed: 20097874]

43. Ma HP, Li L, Zhou ZH, Eaton DC, Warnock DG. ATP masks stretch activation of epithelial sodium channels in A6 distal nephron cells. Am J Physiol Renal Physiol. 2002; 282:F501-F505. [PubMed: 11832432]

44. Ma HP, Saxena S, Warnock DG. Anionic phospholipids regulate native and expressed epithelial sodium channel (ENaC). J Biol Chem. 2002; 277:7641-7644. [PubMed: 11809744]

45. Pochynyuk O, Bugaj V, Vandewalle A, Stockand JD. Purinergic control of apical plasma membrane PI(4,5)P2 levels sets ENaC activity in principal cells. Am J Physiol Renal Physiol. 2008; 294:F38-F46. [PubMed: 17913833]

46. Wildman SS, Marks J, Turner CM, Yew-Booth L, Peppiatt-Wildman CM, King BF, Shirley DG, Wang W, Unwin RJ. Sodium-dependent regulation of renal amiloride-sensitive currents by apical P2 receptors. J Am Soc Nephrol. 2008; 19:731-742. [PubMed: 18235098]

47. Kunzelmann K, Bachhuber T, Regeer R, Markovich D, Sun J, Schreiber R. Purinergic inhibition of the epithelial Na+ transport via hydrolysis of PIP2. FASEB J. 2005; 19:142-143. [PubMed: 15504951]

48. Yue G, Malik B, Yue G, Eaton DC. Phosphatidylinositol 4,5-bisphosphate (PIP2) stimulates epithelial sodium channel activity in A6 cells. J Biol Chem. 2002; 277:11965-11969. [PubMed: 11812779]

49. Ma HP, Eaton DC. Acute regulation of epithelial sodium channel by anionic phospholipids. J Am Soc Nephrol. 2005; 16:3182-3187. [PubMed: 16192420] 
50. Vallon V, Hummler E, Rieg T, Pochynyuk O, Bugaj V, Schroth J, Dechenes G, Rossier B, Cunard $\mathrm{R}$, Stockand J. Thiazolidinedione-induced fluid retention is independent of collecting duct alphaENaC activity. J Am Soc Nephrol. 2009; 20:721-729. [PubMed: 19158355]

51. Stockand JD, Mironova E, Bugaj V, Rieg T, Insel PA, Vallon V, Peti-Peterdi J, Pochynyuk O. Purinergic inhibition of ENaC produces aldosterone escape. J Am Soc Nephrol. 2010; 21:19031911. [PubMed: 20813869]

52. Folkow B, Ely D. Importance of the blood pressure-heart rate relationship. Blood Press. 1998; 7:133-138. [PubMed: 9758081]

53. Sipos A, Vargas SL, Toma I, Hanner F, Willecke K, Peti-Peterdi J. Connexin 30 deficiency impairs renal tubular ATP release and pressure natriuresis. J Am Soc Nephrol. 2009; 20:17241732. [PubMed: 19478095]

54. Mironova E, Peti-Peterdi J, Bugaj V, Stockand JD. Diminished paracrine regulation of the epithelial $\mathrm{Na}+$ channel by purinergic signaling in mice lacking connexin 30. J Biol Chem. 2011; 286:1054-1060. [PubMed: 21075848]

55. McCulloch F, Chambrey R, Eladari D, Peti-Peterdi J. Localization of connexin 30 in the luminal membrane of cells in the distal nephron. Am J Physiol Renal Physiol. 2005; 289:F1304-F1312. [PubMed: 16077080]

56. Ling BN, Kemendy AE, Kokko KE, Hinton CF, Marunaka Y, Eaton DC. Regulation of the amiloride-blockable sodium channel from epithelial tissue. Mol Cell Biochem. 1990; 99:141-150. [PubMed: 1962846]

57. Kemendy AE, Kleyman TR, Eaton DC. Aldosterone alters the open probability of amilorideblockable sodium channels in A6 epithelia. Am J Physiol. 1992; 263:C825-C837. [PubMed: 1329547]

58. Duchatelle P, Ohara A, Ling BN, Kemendy AE, Kokko KE, Matsumoto PS, Eaton DC. Regulation of renal epithelial sodium channels. Mol Cell Biochem. 1992; 114:27-34. [PubMed: 1334227]

59. Taylor AL, Kudlow BA, Marrs KL, Gruenert DC, Guggino WB, Schwiebert EM. Bioluminescence detection of ATP release mechanisms in epithelia. Am J Physiol. 1998; 275:C1391-C1406. [PubMed: 9814989]

60. Wang Y, Roman R, Lidofsky SD, Fitz JG. Autocrine signaling through ATP release represents a novel mechanism for cell volume regulation. Proc Natl Acad Sci U S A. 1996; 93:12020-12025. [PubMed: 8876255]

61. Guns PJ, Van Assche T, Fransen P, Robaye B, Boeynaems JM, Bult H. Endothelium-dependent relaxation evoked by ATP and UTP in the aorta of P2Y2-deficient mice. Br J Pharmacol. 2006; 147:569-574. [PubMed: 16415908]

62. Wang Z, Nakayama T, Sato N, Izumi Y, Kasamaki Y, Ohta M, Soma M, Aoi N, Ozawa Y, Ma Y. The purinergic receptor P2Y, G-protein coupled, 2 (P2RY2) gene associated with essential hypertension in Japanese men. J Hum Hypertens. 2010; 24:327-335. [PubMed: 19710694]

63. Fox ER, Young JH, Li Y, Dreisbach AW, Keating BJ, Musani SK, Liu K, Morrison AC, Ganesh S, Kutlar A, et al. Association of genetic variation with systolic and diastolic blood pressure among African Americans: the Candidate Gene Association Resource study. Hum Mol Genet. 2011; 20:2273-2284. [PubMed: 21378095]

64. Lu M, MacGregor GG, Wang W, Giebisch G. Extracellular ATP inhibits the small-conductance K channel on the apical membrane of the cortical collecting duct from mouse kidney. J Gen Physiol. 2000; 116:299-310. [PubMed: 10919872]

65. Hafting T, Sand O. Purinergic activation of BK channels in clonal kidney cells (Vero cells). Acta Physiol Scand. 2000; 170:99-109. [PubMed: 11114947]

66. Holtzclaw JD, Cornelius RJ, Hatcher LI, Sansom SC. Coupled ATP and potassium efflux from intercalated cells. Am J Physiol Renal Physiol. 2011; 300:F1319-F1326. [PubMed: 21454249]

67. Rieg T, Vallon V, Sausbier M, Sausbier U, Kaissling B, Ruth P, Osswald H. The role of the BK channel in potassium homeostasis and flow-induced renal potassium excretion. Kidney Int. 2007; 72:566-573. [PubMed: 17579662]

68. Woda CB, Bragin A, Kleyman TR, Satlin LM. Flow-dependent K+ secretion in the cortical collecting duct is mediated by a maxi-K channel. Am J Physiol Renal Physiol. 2001; 280:F786F793. [PubMed: 11292620] 
69. Pluznick JL, Sansom SC. BK channels in the kidney: role in $\mathrm{K}(+)$ secretion and localization of molecular components. Am J Physiol Renal Physiol. 2006; 291:F517-F529. [PubMed: 16774904]

70. Rieg T, Tang T, Murray F, Schroth J, Insel PA, Fenton RA, Hammond HK, Vallon V. Adenylate cyclase 6 determines cAMP formation and aquaporin-2 phosphorylation and trafficking in inner medulla. J Am Soc Nephrol. 2010; 21:2059-2068. [PubMed: 20864687]

71. Moeller HB, Olesen ET, Fenton RA. Regulation of the water channel Aquaporin-2 by posttranslational modifications. Am J Physiol Renal Physiol. 2011; 300:F1062-F1073. [PubMed: 21307124]

72. Kishore BK, Nelson RD, Miller RL, Carlson NG, Kohan DE. P2Y(2) receptors and water transport in the kidney. Purinergic Signal. 2009; 5:491-499. [PubMed: 19319665]

73. Rieg T, Vallon V. ATP and adenosine in the local regulation of water transport and homeostasis by the kidney. Am J Physiol Regul Integr Comp Physiol. 2009; 296:R419-R427. [PubMed: 19020292]

74. Kishore BK, Krane CM, Miller RL, Shi H, Zhang P, Hemmert A, Sun R, Nelson RD. P2Y2 receptor mRNA and protein expression is altered in inner medullas of hydrated and dehydrated rats: relevance to AVP-independent regulation of IMCD function. Am J Physiol Renal Physiol. 2005; 288:F1164-F1172. [PubMed: 15687250]

75. Sun R, Miller RL, Hemmert AC, Zhang P, Shi H, Nelson RD, Kishore BK. Chronic dDAVP infusion in rats decreases the expression of P2Y2 receptor in inner medulla and P2Y2 receptormediated PGE2 release by IMCD. Am J Physiol Renal Physiol. 2005; 289:F768-F776. [PubMed: 15914777]

76. Kishore BK, Chou CL, Knepper MA. Extracellular nucleotide receptor inhibits AVP-stimulated water permeability in inner medullary collecting duct. Am J Physiol. 1995; 269:F863-F869. [PubMed: 8594881]

77. Sun R, Carlson NG, Hemmert AC, Kishore BK. P2Y2 receptor-mediated release of prostaglandin E2 by IMCD is altered in hydrated and dehydrated rats: relevance to AVP-independent regulation of IMCD function. Am J Physiol Renal Physiol. 2005; 289:F585-F592. [PubMed: 15840771]

78. Welch BD, Carlson NG, Shi H, Myatt L, Kishore BK. P2Y2 receptor-stimulated release of prostaglandin E2 by rat inner medullary collecting duct preparations. Am J Physiol Renal Physiol. 2003; 285:F711-F721. [PubMed: 12799304]

79. Edwards RM. Basolateral, but not apical, ATP inhibits vasopressin action in rat inner medullary collecting duct. Eur J Pharmacol. 2002; 438:179-181. [PubMed: 11909609]

80. Cha SH, Sekine T, Endou H. P2 purinoceptor localization along rat nephron and evidence suggesting existence of subtypes P2Y1 and P2Y2. Am J Physiol. 1998; 274:F1006-F1014. [PubMed: 9841490]

81. Ecelbarger CA, Maeda Y, Gibson CC, Knepper MA. Extracellular ATP increases intracellular calcium in rat terminal collecting duct via a nucleotide receptor. Am J Physiol. 1994; 267:F9981006. [PubMed: 7810708]

82. Wildman SS, Boone M, Peppiatt-Wildman CM, Contreras-Sanz A, King BF, Shirley DG, Deen PM, Unwin RJ. Nucleotides downregulate aquaporin 2 via activation of apical P2 receptors. J Am Soc Nephrol. 2009; 20:1480-1490. [PubMed: 19423692]

83. Zhang Y, Sands JM, Kohan DE, Nelson RD, Martin CF, Carlson NG, Kamerath CD, Ge Y, Klein JD, Kishore BK. Potential role of purinergic signaling in urinary concentration in inner medulla: insights from P2Y2 receptor gene knockout mice. Am J Physiol Renal Physiol. 2008; 295:F1715F1724. [PubMed: 18829742]

84. Odgaard E, Praetorius HA, Leipziger J. AVP-stimulated nucleotide secretion in perfused mouse medullary thick ascending limb and cortical collecting duct. Am J Physiol Renal Physiol. 2009; 297:F341-F349. [PubMed: 19515810]

85. Zhang Y, Pop IL, Carlson NG, Kishore BK. Genetic deletion of the P2Y2 receptor offers significant resistance to development of lithium-induced polyuria accompanied by alterations in PGE2 signaling. Am J Physiol Renal Physiol. 2012; 302:F70-F77. [PubMed: 21975874]

86. Crawford C, Kennedy-Lydon TM, Callaghan H, Sprott C, Simmons RL, Sawbridge L, Syme HM, Unwin RJ, Wildman SS, Peppiatt-Wildman CM. Extracellular nucleotides affect pericyte- 
mediated regulation of rat in situ vasa recta diameter. Acta Physiol (Oxf). 2011; 202:241-251. [PubMed: 21624094]

87. Wang H, Wang DH, Galligan JJ. P2Y2 receptors mediate ATP-induced resensitization of TRPV1 expressed by kidney projecting sensory neurons. Am J Physiol Regul Integr Comp Physiol. 2010; 298:R1634-R1641. [PubMed: 20335377]

88. Namba K, Suzuki T, Nakata H. Immunogold electron microscopic evidence of in situ formation of homo- and heteromeric purinergic adenosine $\mathrm{A} 1$ and $\mathrm{P} 2 \mathrm{Y} 2$ receptors in rat brain. BMC Res Notes. 2010; 3:323. [PubMed: 21114816]

89. Sumi Y, Woehrle T, Chen Y, Yao Y, Li A, Junger WG. Adrenergic receptor activation involves ATP release and feedback through purinergic receptors. Am J Physiol Cell Physiol. 2010; 299:C1118-C1126. [PubMed: 20668211]

90. Bailey MA, Imbert-Teboul M, Turner C, Marsy S, Srai K, Burnstock G, Unwin RJ. Axial distribution and characterization of basolateral $\mathrm{P} 2 \mathrm{Y}$ receptors along the rat renal tubule. Kidney Int. 2000; 58:1893-1901. [PubMed: 11044209]

91. Kishore BK, Ginns SM, Krane CM, Nielsen S, Knepper MA. Cellular localization of P2Y(2) purinoceptor in rat renal inner medulla and lung. Am J Physiol Renal Physiol. 2000; 278:F43-F51. [PubMed: 10644654]

92. Bailey MA, Imbert-Teboul M, Turner C, Srai SK, Burnstock G, Unwin RJ. Evidence for basolateral P2Y(6) receptors along the rat proximal tubule: functional and molecular characterization. J Am Soc Nephrol. 2001; 12:1640-1647. [PubMed: 11461936]

93. Turvey MR, Wang Y, Gu Y. The effects of extracellular nucleotides on [Ca2+]i signalling in a human-derived renal proximal tubular cell line (HKC-8). J Cell Biochem. 2010; 109:132-139. [PubMed: 19937734]

94. Yamada H, Seki G, Taniguchi S, Uwatoko S, Suzuki K, Kurokawa K. Mechanism of [Ca2+]i increase by extracellular ATP in isolated rabbit renal proximal tubules. Am J Physiol. 1996; 270:C1096-C1104. [PubMed: 8928737]

95. Bailey MA. Inhibition of bicarbonate reabsorption in the rat proximal tubule by activation of luminal P2Y1 receptors. Am J Physiol Renal Physiol. 2004; 287:F789-F796. [PubMed: 15172882]

96. Mo J, Fisher MJ. Uridine nucleotide-induced stimulation of gluconeogenesis in isolated rat proximal tubules. Naunyn Schmiedebergs Arch Pharmacol. 2002; 366:151-57. [PubMed: 12122502]

97. Cha SH, Jung KY, Endou H. Effect of P2Y-purinoceptor stimulation on renal gluconeogenesis in rats. Biochem Biophys Res Commun. 1995; 211:454-461. [PubMed: 7794257] 


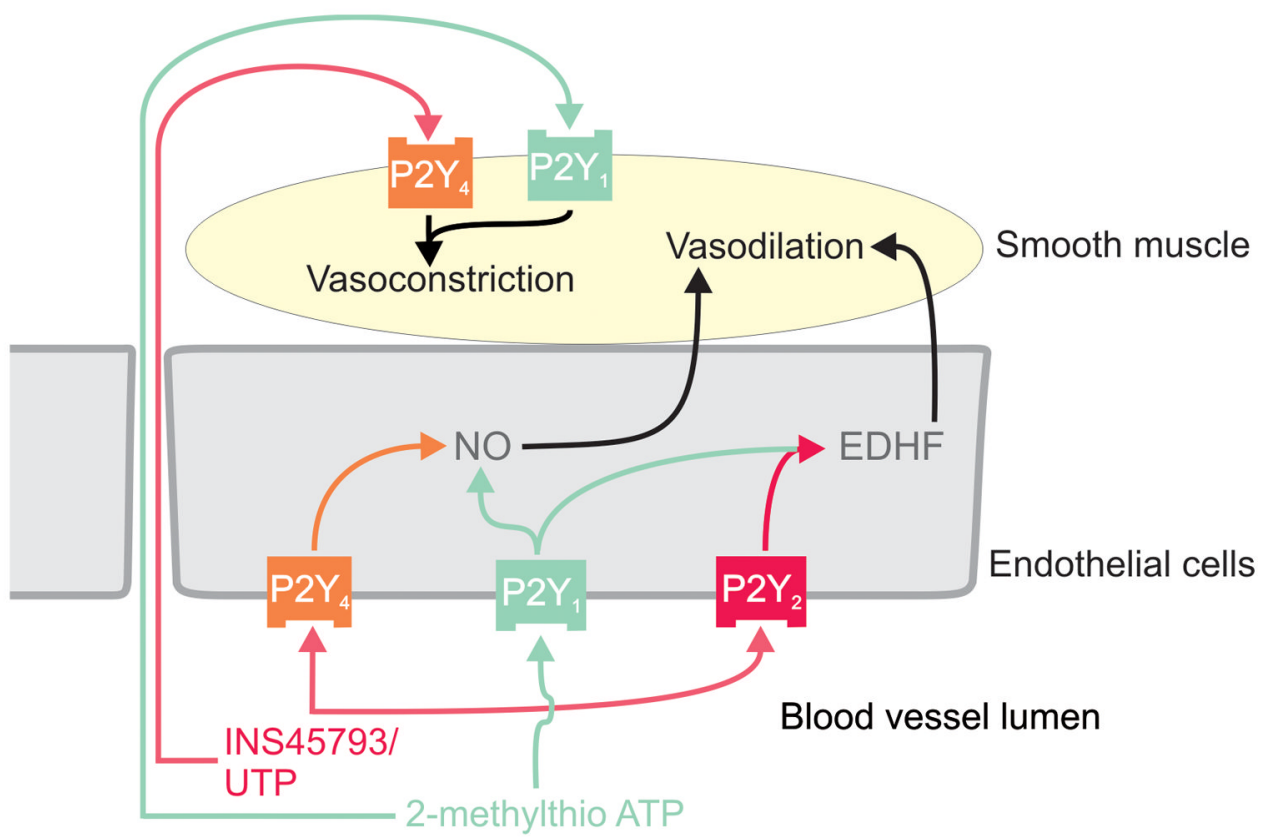

Figure 1. A proposed model for the regulation of vascular tone by $\mathrm{P} 2 \mathrm{Y}$ receptors Depicted are localizations and vascular responses to activation of $\mathrm{P}_{2} \mathrm{Y}_{1}$ (activated by ATP, 2-methylthio ATP), P2Y 2 (ATP/UTP/INS45973) and P2Y 4 (ATP/UTP/INS45973) receptors. Activation of $\mathrm{P} 2 \mathrm{Y}_{1}$ receptors on endothelial cells induces endothelium-dependent vasodilation utilizing nitric oxide (NO) and endothelial derived hyperpolarization factor (EDHF). Activation of $\mathrm{P}_{2} \mathrm{Y}_{4}$ receptors on endothelial cells lowers vascular tone through release of endothelial NO; in comparison, activation of $\mathrm{P}_{2} \mathrm{Y}_{2}$ receptors on endothelial cells induces vasodilation independent of endothelial $\mathrm{NO}$ and may involve EDHF. Activation of smooth muscle $\mathrm{P}_{2} \mathrm{Y}_{1}$ or $\mathrm{P}_{2} \mathrm{Y}_{4}$ receptors results in vasoconstriction. Based on and modified from ${ }^{24}$. 

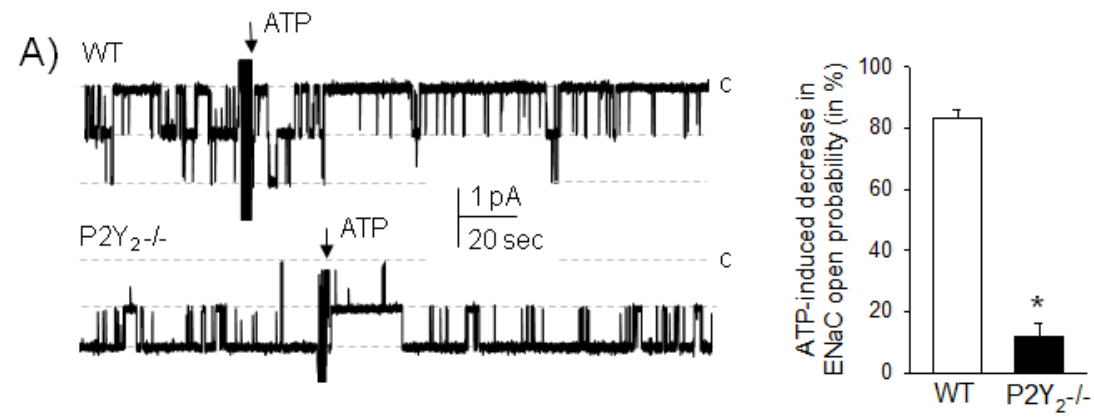

B)

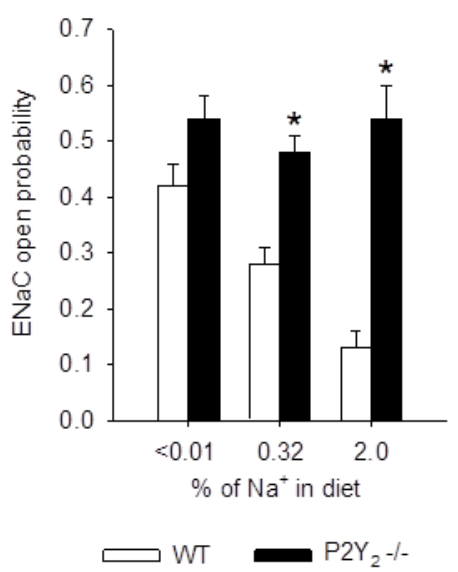

C)

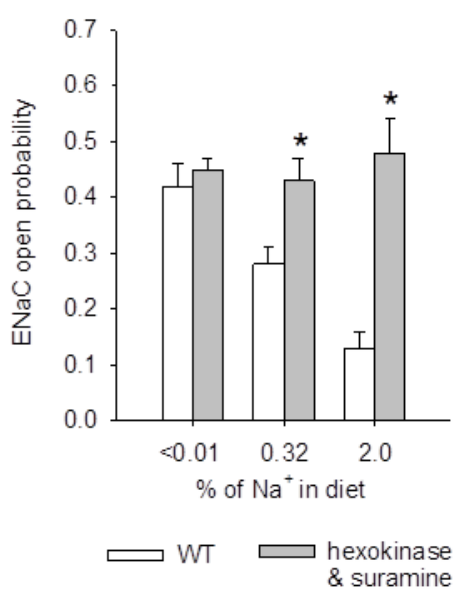

Figure 2. The inhibitory effect of ATP and dietary $\mathrm{NaCl}$ on $\mathrm{ENaC}$ open probability $\left(\mathrm{P}_{O}\right)$ in the aldosterone-sensitive distal nephron is mediated by $\mathrm{P}_{2} \mathrm{Y}_{2}$ receptor activation

A) Continuous current traces from cell-attached patches on principal cells (containing $\geq$ two ENaC's) before and after application of ATP $(100 \mu \mathrm{M})$ in CNTs/CCDs harvested from WT and $\mathrm{P} 2 \mathrm{Y}_{2}-1-$ mice fed a regular $0.32 \% \mathrm{Na}^{+}$diet. Patches clamped to $-\mathrm{Vp}=-60 \mathrm{mV}$ and inward $\mathrm{Li}^{+}$currents through $\mathrm{ENaC}$ are downward. Dashed lines indicate the respective current levels; c denotes the closed state. Summary graphs of ENaC Po changes in response to ATP are shown on the right. * $P<0.05$ vs WT. B) The suppression of ENaC $\mathrm{P}_{\mathrm{O}}$ by dietary $\mathrm{NaCl}$ intake is absent in $\mathrm{P} 2 \mathrm{Y}_{2}-/-$ mice. $* P<0.05$ vs. WT. C) Inhibition of local ATP signaling (hexokinase (+glucose) to degrade local ATP plus suramin to prevent $\mathrm{P} 2$ receptor activation) prevents regulation of $\mathrm{ENaC}_{\mathrm{O}}$ by dietary $\mathrm{NaCl}$ intake in WT mice. ${ }^{*} P<0.05$ vs. WT control. Based on and modified from ${ }^{42}$. 


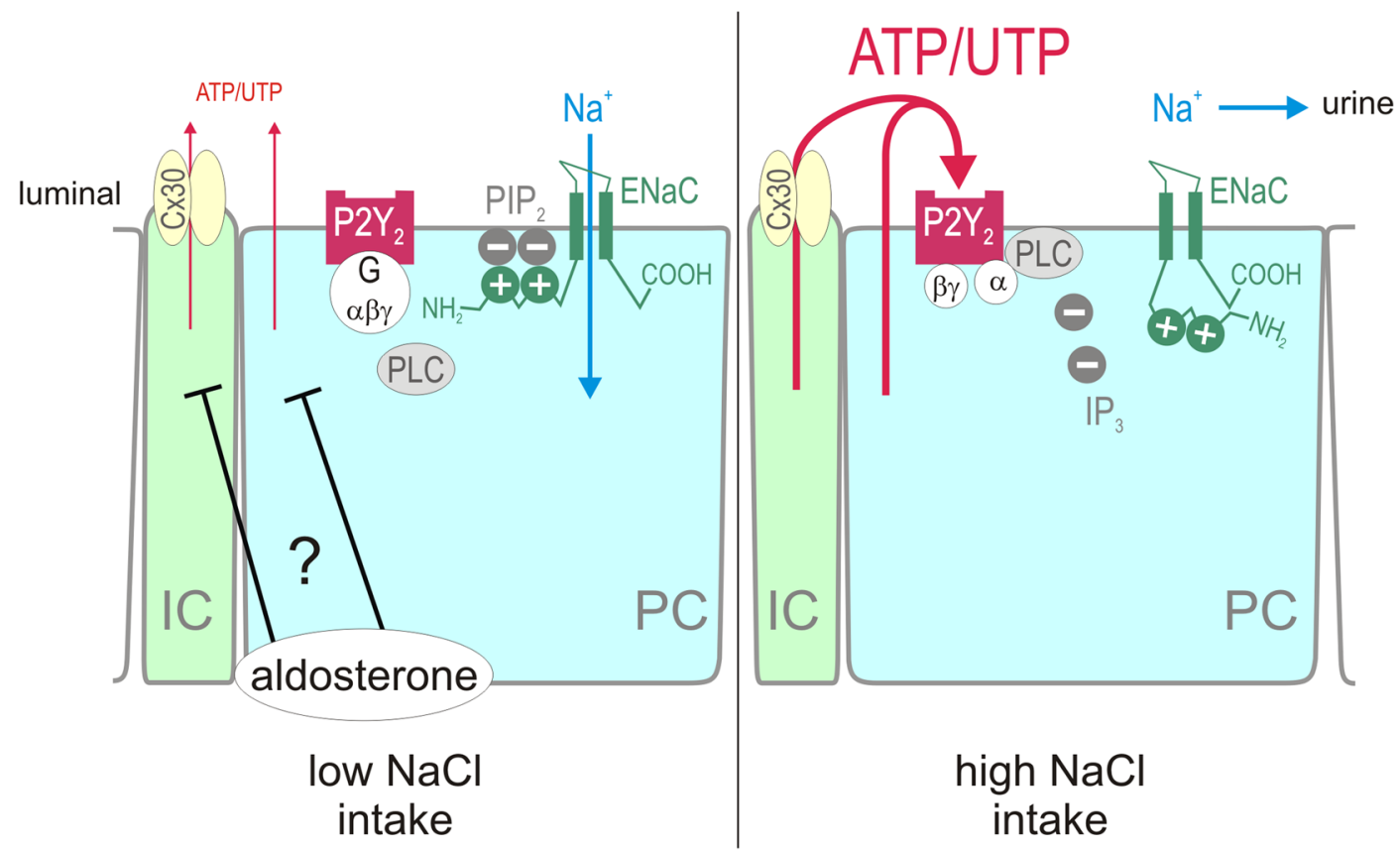

Figure 3. A proposed model for the inhibition of $\mathrm{ENaC}$ open probability $\left(\mathrm{P}_{\mathrm{O}}\right)$ by dietary $\mathrm{NaCl}$ in the aldosterone-sensitive distal nephron

Low dietary $\mathrm{NaCl}$ intake suppresses luminal release of ATP and UTP which may relate to increased aldosterone levels. This prevents activation of apical $\mathrm{P} 2 \mathrm{Y}_{2}$ receptors on principal cells (PC). As a consequence, the inner leaflet of the lipid bilayer contains a high concentration of negatively-charged phosphatidylinositol 4,5-bisphosphate $\left(\mathrm{PIP}_{2}\right)$, which binds to positively charged regions of the $\mathrm{N}$-terminus of the $\beta$-subunit of $\mathrm{ENaC}$, thereby maintaining the $\mathrm{ENaC}$ channel open and active. High dietary $\mathrm{NaCl}$ intake increases the luminal release of ATP and UTP, at least in part via a connexin30 (Cx30)-dependent mechanism in intercalated cells (IC). This activates apical $\mathrm{P} 2 \mathrm{Y}_{2}$ receptors and phospholipase $\mathrm{C}$ (PLC), which hydrolyzes and lowers the concentration of $\mathrm{PIP}_{2}$. The resulting conformation change in the $\mathrm{N}$-terminus of $\beta$-ENaC lowers $\mathrm{ENaC} \mathrm{P}_{\mathrm{O}}$ and activity, and increases $\mathrm{Na}^{+}$excretion. See text for details. $\mathrm{IP}_{3}$, inositol trisphosphate. Modified from ${ }^{2}$. 


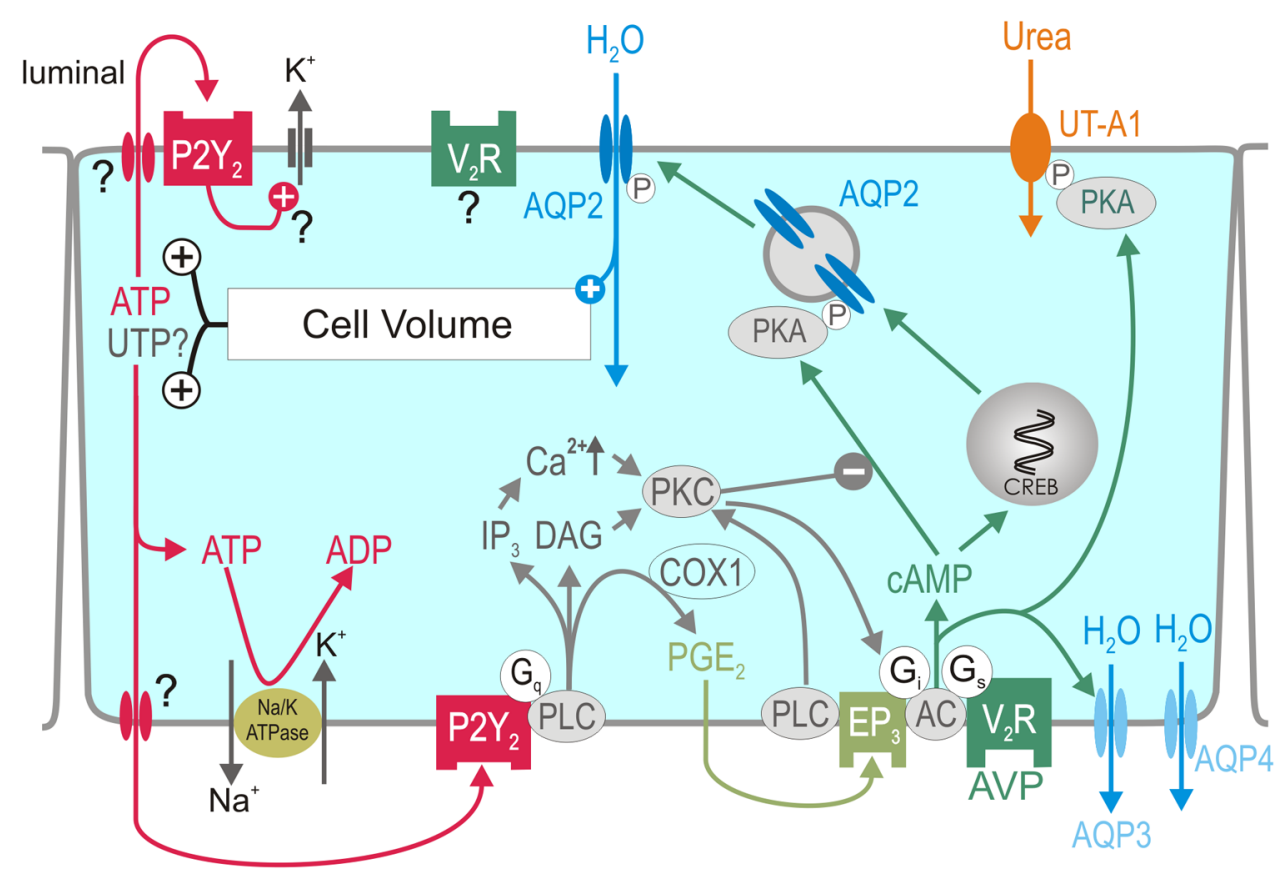

Figure 4. A proposed model for cell volume-dependent ATP release and water transport inhibition by $P 2 Y_{2}$ receptor activation in IMCD cells

Arginine-vasopressin (AVP) activates vasopressin $V_{2}$ receptor $\left(V_{2} R\right)$ to stimulate aquaporin-2 mediated water entry which increases cell volume. The latter increases basolateral and apical release of ATP (and potentially UTP?) by unknown mechanism. P2 $\mathrm{Y}_{2}$ receptor activation inhibits water reabsorption via multiple signaling pathways and stimulates volume regulatory $\mathrm{K}^{+}$channels as shown in other cell types. These effects help to stabilize cell volume. In response to an acute water load, the relative hypotonic extracellular fluid may increase cell volume. The resulting release of nucleotides and activation of $\mathrm{P}_{2} \mathrm{Y}_{2}$ receptor stabilizes cell volume and accelerates the excretion of free water before circulating AVP levels fall. AC, adenylyl cyclase; AQP2, -3, -4, aquaporin-2, -3, -4; COX1, cyclooxygenase 1; CREB, cAMP responsive element-binding protein; DAG, diacylglycerol; $\mathrm{EP}_{3}, \mathrm{PGE}_{2} \mathrm{E}_{3}$ receptor; ET-1, endothelin 1; ETB, endothelin B receptor; $\mathrm{G}_{\mathrm{i}}$, inhibitory $\mathrm{G}$ protein; $\mathrm{Gq}, \mathrm{G}_{\mathrm{s}}$, stimulatory $\mathrm{G}$ protein; $\mathrm{IP}_{3}$, inositol trisphosphate; $\mathrm{P}$, phosphorylation; $\mathrm{PGE}_{2}$, prostaglandin $\mathrm{E}_{2}$; PLC, phospholipase $\mathrm{C}$; PKA, protein kinase A; PKC, protein kinase C; UT-A1, urea transporter A1. Modified from ${ }^{2}$. 
A)

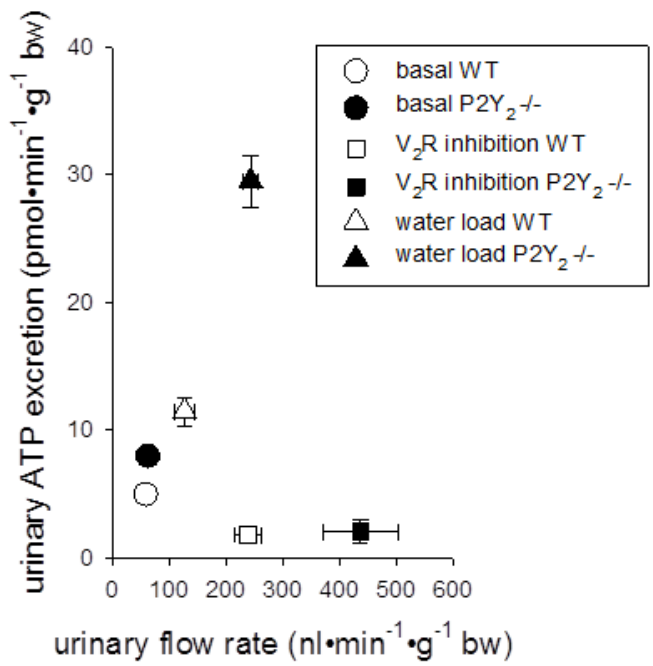

B)

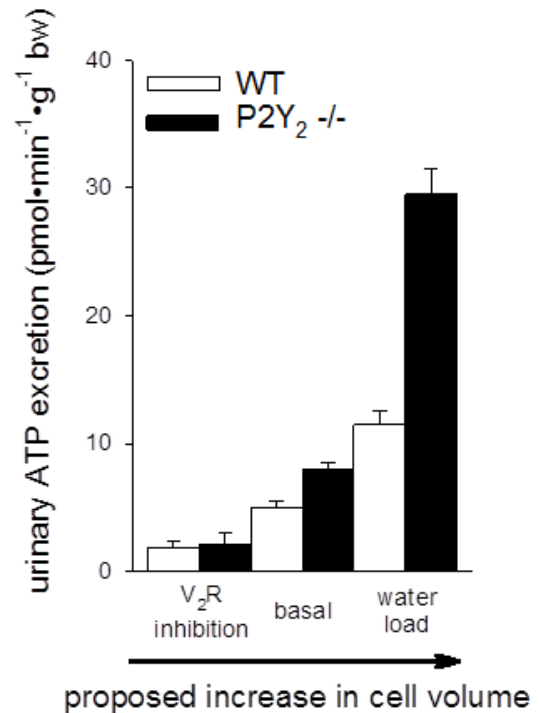

Figure 5. Indirect evidence for a positive relationship between collecting duct cell volume and ATP release, and a role of $P 2 Y_{2}$ receptors in stabilizing cell volume

Quantitative urine collection was performed in $\mathrm{P}_{2} \mathrm{Y}_{2}-/-$ mice and littermate wild types (WT) in metabolic cages over 2 hours following acute vasopressin $\mathrm{V}_{2}$ receptor inhibition $\left(\mathrm{V}_{2} \mathrm{R}-\mathrm{I}\right)$ or acute oral water loading (WL). (A) $\mathrm{V}_{2} \mathrm{R}-\mathrm{I}$ and WL both increased urinary flow rate but induced opposite effects on urinary ATP excretion. Urinary flow rate is not a good predictor of urinary ATP excretion. (B) $V_{2} R-I$ is expected to reduce CD water uptake and thus $\mathrm{CD}$ cell volume. In contrast, the reduction in extracellular tonicity associated with WL may increase $\mathrm{CD}$ cell volume. If an increase in cell volume induces ATP release, which stabilizes cell volume via inhibition of water uptake through a $\mathrm{P} 2 \mathrm{Y}_{2}$ receptor-mediated mechanism, then ATP release is expected to be enhanced in $\mathrm{P}_{2} \mathrm{Y}_{2}-1-$ mice. This influence should be minimized by reducing water uptake by $\mathrm{V}_{2} \mathrm{R}-\mathrm{I}$ and maximized by water loadinginduced cell swelling. Based on 23 and modified from ${ }^{73}$. 
Table 1

Expression of P2Y receptors along the native tubule and collecting duct system

\begin{tabular}{|c|c|c|c|}
\hline & proximal tubules & loop of Henle & collecting duct \\
\hline $\mathrm{P} 2 \mathrm{Y}_{1}$ & $\begin{array}{l}\text { IM: PST-A }{ }^{15} ; \text { mRNA: } \\
\text { PCT }{ }^{90}\end{array}$ & mRNA: tDL, tAL, mTAL 90 & mRNA: OMCD 90 \\
\hline $\mathrm{P} 2 \mathrm{Y}_{2}$ & mRNA: PCT ${ }^{90 ; 91} ;$ PST $^{91}$ & $\begin{array}{l}\text { IM: tAL, mTAL (intra), cTAL } \\
\text { (intra) }{ }^{15} ; \text { mRNA: tDL, } \\
\text { tAL }^{90 ; 91}, \text { mTAL }^{90 ; 91}, \text { cTAL }^{91}, \\
\text { mouse mTAL }^{31}\end{array}$ & $\begin{array}{l}\text { IM: CCD (PC and IC, PC: intra) }{ }^{46} \text {; OMCD (PC and IC, PC: } \\
\text { intra-A/B) }{ }^{46} \text {; MCD IC }{ }^{15} \text {, IMCD (A>B) }{ }^{91} \text {;MCD (PC and IC, } \\
\text { PC: B>A) } \text { IMC; WB: IMCD }^{91} ; \text { mRNA: CD }{ }^{46} ; \text { CCD }^{91} \\
\text { OMCD } \\
{ }^{90} ; 91 \text {, IMCD }\end{array}$ \\
\hline $\mathrm{P}_{2} \mathrm{Y}_{4}$ & $\begin{array}{l}\text { IM: PCT (B) }{ }^{15} ; \text { mRNA: } \\
\text { PCT } 90\end{array}$ & mRNA: tAL, mTAL 90 & $\begin{array}{l}\text { IM: CCD, OMCD, IMCD (PC and IC, PC: all A); mRNA: } \\
\text { OMCD }{ }^{90} ; \mathrm{CD} \text { (NaCl restriction) }{ }^{46}\end{array}$ \\
\hline $\mathrm{P} 2 \mathrm{Y}_{6}$ & mRNA: PCT, PST $^{92}$ & 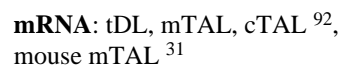 & $\begin{array}{l}\text { IM: } \mathrm{CCD}, \mathrm{OMCD}, \mathrm{IMCD}\left(\mathrm{PC} \text { and IC, PC: all intra-A) }{ }^{46} \text {; }\right. \\
\text { mRNA: CD }{ }^{46} \text {; CCD, OMCD }{ }^{92}\end{array}$ \\
\hline
\end{tabular}

P2Y11-14 have not been identified unequivocally in the kidney and therefore were not included in the table. (A), apical; (B), basolateral; CCD, cortical collecting duct; $\mathrm{CD}$, collecting duct; cTAL, cortical thick ascending limb; IC, intercalated cells; IM, immunostaining; IMCD, inner medullary collecting duct; (intra), intracellular; OMCD, outer medullary collecting duct; PC, principal cell; PCT, proximal convoluted tubule; PST, proximal straight tubule; tAL, thin ascending limb; mTAL; tick ascending limb; tDL, thin descending limb; WB, Western blotting. All studies performed in rat kidney unless otherwise stated. Modified from ${ }^{1}$. 


\section{Table 2}

Effects of P2Y receptor activation in proximal tubules

\begin{tabular}{|c|c|c|}
\hline Receptor & Effect & Method (site of effect) criteria for receptor subtype \\
\hline $\mathrm{P} 2 \mathrm{Y}$ & {$\left[\mathrm{Ca}^{2+}\right]_{\mathrm{i}} \uparrow$ via PLC, TRP channel } & human-derived renal PT cell line (HKC-8) ${ }^{93}$ \\
\hline $\mathrm{P} 2 \mathrm{Y}_{1}, \mathrm{P}_{2} \mathrm{Y}_{2}$-like & {$\left[\mathrm{Ca}^{2+}\right]_{\mathrm{i}} \uparrow$} & isolated rabbit or rat $\mathrm{PT}(\mathrm{B})^{80 ; 90 ; 94}$ \\
\hline $\mathrm{P}^{2} \mathrm{Y}_{1}$ & bicarbonate reabsorption $\downarrow$ & rat micropuncture in vivo (A) ${ }^{95}$ \\
\hline $\mathrm{P} 2 \mathrm{Y}_{2}$-like & {$\left[\mathrm{Ca}^{2+}\right]_{\mathrm{i}} \uparrow$, gluconeogenesis $\uparrow, \mathrm{Ca}^{2+}$ and PLC-dependent } & rat renal cortical tubule suspensions or isolated rat PT (B) ${ }^{96 ; 97}$ \\
\hline $\mathrm{P} 2 \mathrm{Y}_{6}$ & {$\left[\mathrm{Ca}^{2+}\right]_{\mathrm{i}} \uparrow$ and IP $\uparrow$} & isolated rat $\mathrm{PT}(\mathrm{B}){ }^{92}$ \\
\hline
\end{tabular}

(A), apical effect; (B), basolateral effect; IP, inositol phosphates; PLC, phospholipase C; TRP, transient receptor potential. Modified from ${ }^{1}$. 